\title{
COLLATERAL BEAUTY. NIETZSCHE'S THOUGHTS ON ARCHITECTURE
}

\section{A B S T R A C T}

With his interpretation of the Apollonian and Dionysian psychological states, Nietzsche was trying to correlate prominent dichotomies of his era - reason and instinct, science and metaphysic, experience and thinking, knowledge and inspiration, representation and unity, order and chaos. He was acting as a critic of the whole Western cultural output through these dualisms. This essay analyses a handful of Nietzsche's aphorisms that are directly or indirectly related to the art of a building. In them, Nietzsche was conjuring an idea of the new architecture that would oppose the ideal of the building in the 19thcentury: the architecture does not idealise, it is not a mere appearance, it is built in the spirit of its time, it makes us want to move into it and ultimately it is the architecture where beauty is not an end but a means to an end.

\section{Mirza Vranjaković}




\section{INTRODUCTION}

Nietzsche was never too shy to show great erudition. Sometimes in only one aphorism he easily covers several eras, connects thinkers that are born in different millennia, criticises antic plays alongside with contemporary art, only to finish with his vision and a new concept. On the one hand, reading Nietzsche is delightful, one gets easily captivated by his metaphors, unexpected twists and turns and surprising jokes. On the other hand, in order to grasp Nietzsche's ideas, it is crucial to understand the historic context in which he created his work; the context of two contested perceptions of the universe, a human being, knowledge and morality.

Here I would like to propose that the scientific revolution in the seventeenth century marks the beginning of the rudimental historical frame. In less than a century, Nicolaus Copernicus placed the Sun rather than the Earth at the centre of the universe; René Descartes affirmed the existence of a thinking entity and, thus, paved the way for the new self-awareness of the man. Isaac. Newton showed that everything behaves under the certain laws of physics. These discoveries mark the new era in which a man was able to use his reason and science to explain the world and its phenomena. It was the birth of the new optimistic Weltanschauung. Nevertheless, this awakening of the modern mind was paradoxical in its effect. By explaining the universe, it positioned man at the centre of it; a thinking entity that comprehends and explains, demystifies and creates. Man did not need mythology or religion anymore, he found new faith, the faith in reason and the human being itself. On the other side, the demystified man was nothing more than any other living being in this impersonal and purely scientific universe. The universe was no longer the space created for the selfrealisation and redemption of human kind, but an unconscious reality that does not recognise human superiority. In other words, the humanity was moved by scientific optimism and existential pessimism.

From this point on, Europe will see the secularisation and the abolition of the feudal system, industrial revolution and the conquest of nature, the technological progress and life quality improvement, urbanisation and emancipation, but at the same time new power structures will emerge and the production of social relationships will change, overpopulation and deeper inequalities will be born out of massive industrialisation and urbanisation. Out of this ambiguous condition the two ways of dealing with it are born. We can observe them as two ways of seeing the world, two sensibilities or two temperaments which mark the division between the thinkers in the nineteenth century. On the one hand, 
rationalists and empiricists were represented by the thinkers who praised the power of human mind and knowledge, believing that the universe is reducible to the laws of physics. They were convinced in the man's ability to progress through science and the conquest of nature. Opposing rational thought were romanticists who perceived the universe as a spiritual substance on which human being depends on. They valued imagination and the will over the objective and fundamental knowledge. Whereas rationalists had faith in inevitable human advance, romanticists accepted the drama of human existence and praised the responses and emotions born out of it. The manifestations of these sentiments through art gained the status of religion and artists were celebrated as prophets of human soul.

It is also important to mention that these two groups are not completely opposite of each other: both are humanist in its basis, concerned with human consciousness while praising the greatness of human being. But there are some opposing concepts that polarised these two sentiments, like the perception of nature or history (classic culture), for instance. Romanticists regarded nature as an ever-changing spirit that provides many different possibilities for reading it and saw it as is the biggest source of inspiration, while rationalists were trying to probe it and explain its ways of working objectively. Similar to this point, rationalists were interested in classic culture from the historic and scientific perspective, while romanticists saw it as a well of genius, praising it for its artistic output, reason and understanding of beauty. All of that being said, it is easy to see that romantic thinkers' understanding of the world came from art instead of science and human nature, or rather their thoughts were directed toward the inside, seeking an explanation of the universe through emotions.

Nietzsche was raised and educated in this environment of dichotomies and opposing concepts of the world perception. We could even say that Nietzsche embodies these two sentiments: on the one side a passionate nature and ardour for art, and on the other a rigorous upbringing in a religious family and the extreme skepticism which was prevalent in education during the Age of Enlightenment, the era when aggressive industrialisation negated the optimism of the human progress through knowledge.

CONCEPT OF DIONYSIAN AND APOLLONIAN PSYCHOLOGICAL STATES

In his earliest work, The Birth of Tragedy, published in 1872 as a doctoral thesis, Nietzsche introduces the concepts of Dionysian and Apollonian psychological 
states. When it came out, the lack of formal academic composition enraged the academic community of its time. Nevertheless, the alternative writing style allowed Nietzsche to paint a dynamic history not only of the Greek tragedy but art in general. With these two concepts, he creates the lenses through which he criticises the contemporary cultural output in his later work and uses them to anticipate a new ideal art or in his words "the rebirth of tragedy."

In this work, Nietzsche suggests that there is nothing beyond the existence, in other words there is no meaning to it. Human being is from its early stage confronted with "the terror and horror of existence" 2 and has trough ages responded differently to this. In the antic Greek culture, the mythology served as a justification for life, imagining the Olympian gods, the all-too-human deities who "justify the lives of men because they themselves live it." ${ }^{\text {"3 Fom }}$ this point, Nietzsche sets forth three different responses to the reality found in ancient Greece: the Dionysian, Apollonian and Socratic.

The Dionysian can be described as a response that mimics a chaotic reality, relives it and immerses itself in it. It takes its name from Dionysus, the Greek god of wine and ritual madness who symbolised pain and suffering as well as the rupture and ecstasy of drunkenness. With this concept Nietzsche was trying to portray the psychological state of intoxication in which one forgets about his/ her own individuality and dissolves into collective expression. The Dionysian festivals are nothing more than that - unifying and identifying with nature and reality. But the pure Dionysian state - "the Barbaric Dionysian"4 - leads to violence and sexual desire, producing meaningless chaos.

The Apollonian, on the other hand, is an attempt to bring order to reality. Compared to the Dionysian intoxication, Nietzsche sees the Apollonian as a dream or a vision, which encourages contemplative state. In other words, the Apollonian imagines illusions that help us deal with life. It forces itself on the Dionysian and covers it "as a veil", producing a "mere appearance" that prevents us from looking into the reality of things.

Nietzsche analyses the development of the ancient Greek culture that precedes the Attic tragedy, that he held as a paragon of artistic expression. In his analysis, we see that the Dionysian and Apollonian are not antagonistic concepts and we should not, by any means, look at them as Hegelian concepts of thesis and antithesis. The history of Greek culture is rather an interplay of these two forces, with a climax reached in tragedy, suggests Nietzsche. Accordingly, the pre-Hellenistic period (the Titans), marked by the rule of the Dionysian force, 
is violently conquered by the Olympian gods representing the Apollonian force, bringing order to the world. Then we see further development in two antic figures, Homer being "the ancient self-absorbed dreamer" and Archilochus "the fighting servant of the muses, battered by existence." $"$ The former represents a strong Apollonian and the latter Dionysian force. Homer's epics could be read as a sequence of images or dreams that do not represent the world as it is, but create one that is easily understandable. We can compare Homer's work to the Greek sculptures, which we are to observe and then contemplate on. Archilochus introduced the folk song to literature and bridged the void between music and poetry. Nietzsche calls him "the first lyric poet among Greeks" and notes that he was writing about feelings and the intoxication by frenzy, all while not trying to glorify the mankind. In his lyric poetry we can observe how the "the language of poetry most strongly pressured to imitate music" not represent the world, instead it opens itself to empathy and immersion, it drives us to live it. Here we can see the opposition of Apollonian art of Greek sculpture and pottery and that of Dionysian art of music and lyric poetry. As I have mentioned before these two forms of art will culminate in the Attic Tragedy of Sophocles. In his work, there are two elements which represent tragedy: Chorus that leads us through the play with singing and dancing, and actors that represent what is happening by creating imagery. Nietzsche saw Chorus as a Dionysian element that immerses itself in the play thus helping spectators to do the same. Chorus does not try to explain tragedy, but rather relives it. Actors, as the Apollonian force, give us a visual illusion of the plot and are often even absent from the scene in the portrayal of tragic events such as a murder, suicide or rape. By doing this Sophocles is avoiding the reduction of tragedy to the imagery.

With Socrates and his philosophy, in the next stage of Hellenistic period, we see the emergence of a new way of responding to reality whereby reality is a logical system that we can comprehend and explain. Socrates's moral postulates where the knowledge is a precondition for goodness paved the way for new optimism that would eventually take away the choir, dance and the tragedy itself out of Attic tragedy. This quest for knowledge and the desire to make sense out of all things was a new force of inspiration for Euripides. As a result of this antic enlightenment project the "Greek tragedy perished as a work of art."

In the Attic tragedy, Nietzsche sees the ability of the Greeks to accept the tragedy of human existence as great health. In Sophocles' plays the tragedy is affirmed by the fact that no character is larger than reality. The tragedy was not seen as a redemption or atonement but, on the contrary, it is like a window through which 
spectators have an opportunity to peek into terrors and horrors of the existence. And it is precisely this recognition of tragedy and catharsis that follows it that the contemporary society lacks, according to Nietzsche.

\section{ARCHITECTURE IN NIETZSCHE'S APHORISMS}

In his following works, Nietzsche continues to analyse the Western cultural production. In handful of his aphorisms he is dealing with architecture, comparing it with other arts, searching for the beauty in it and criticising the contemporary architectural taste. Below, I will try to go over the mentioned aphorisms and form a narrative that would present Nietzsche's thoughts as to questions that arise from the phrase the art of building ${ }^{10}$ : What is art? How does the artist create art and how do we perceive it? Is architect an artist? What is beautiful in architecture?

When explaining the process of creation of art and its effects, Nietzsche starts with his concept of intoxication. ${ }^{11}$ According to him, the feeling of intoxication is "one physiological precondition ... indispensable for there to be art or any sort of aesthetic action or vision." 12 In this state we are empowered to distort things, reduce them to their main features, in other words to idealise them. Nietzsche continues to explain that the art is born out of this need to idolise: "This need to make perfect is - art."13 As food for thought Nietzsche poses the question of an anti-artist, the one that does the opposite of idolising and we are left wondering what kind of a need would that be and whether that toois born out of intoxication. In both cases he is talking about the need,instinct or desire, something that comes from inside. Using the concepts already defined in The Birth of Tragedy, he makes a distinction between the Apollonian and Dionysian type of artists and their respective intoxications, where the former "stimulates the eye above all, so that it gets the power of vision" and with latter "the entire system of affects is excited and intensified." ${ }^{14}$

In the next aphorism Nietzsche positions architects outside of the Apollonian and Dionysian state, reasoning that they "have always been inspired by the most powerful people" and "under the spell of power." 15 He further argues that the will to power is perfectly rendered through architecture. Even though he does not give much of an explanation, we can grasp what he means by this. To him, an architect does not have the same need to build as an artist has to produce art. The architect is not inspired from inside, like other artists, but rather commissioned by a powerful individual and is inspired by this person's power. 
In other words, the architect has to fulfill the desires of his client, conquer the gravity and manifest the power through form, which could hardly be described as fulfillment of a need.

It could be argued that architects do not want to see themselves merely as Michel Foucault's 'dispositif' 16 , an instrument of power, they do not want to be denied of this need to build, to idealise and to create a space that will awaken our senses. It is easy to be seduced by the Apollonian and Dionysian concepts and to apply them in the analysis of architecture or architects for that matter. But as mentioned above in the analysis of these two ideas, they represent responses to the reality and the following actions upon this instinct. If we apply it as such to architecture, we are going to fall short in our analysis. Architects are driven by different forces that produce a variety of responses to the given realities posed by the conditions of the project.

On the other side of the art work / building there is the reception and understanding of it. Nietzsche addresses the recipient of the art work (spectator, patron, concert visitor or building visitor) in many of his aphorisms. We can follow his thought in a couple of them in Human All Too Human. He takes music as an example to explain the understanding of a non-representative art. The same way we learn to understand each other's gestures because of the language that follows it, our ears learn through "long habituation to the juxtaposition of music and movement"17 to understand different tones and interpret them. Now we do not even need to see a dancer's movements or feelings of an actor following music in order to understand it. Nietzsche sees in this "the desensualisation of higher art"18 and points to a world in which the art is only understood with our brain and not our senses. The result is "the world is uglier than ever, but it signifies a more beautiful world than there has ever been."19 The same goes for other arts where pleasure is transferred from our sensory organs to the brain.

Nietzsche argues further that "in general we no longer understand Architecture ... We have grown out of the symbolism of lines and figures" ${ }^{20}$ and buildings are no longer loaded with meaning as was the case with Greek and Christian buildings. Here he observes that this total significance acted as a magic veil ${ }^{21}$ over the building. The word veil can be understood as an Apollonian illusionmaking tool, but here it is a metaphor for a layer that does not hide everything completely, but gives us hints about shape and characteristics of the covered object. Beauty was not an aim in antic buildings, but it would come along the process and it would serve to 'mitigate the dread'22. This view of beauty was contrary to the contemporary understanding of architecture in nineteenth 
century. The beauty of the eclectic combinations of elements that are relieved of any coherence and function. Nietzsche criticises these eclectic buildings and neo-classical taste of European architects by saying that the beauty of the contemporary buildings is "The same thing as the beautiful face of a mindless woman: something mask-like."23

And Nietzsche does not explicitly mention the building style, we can understand that the facades of the buildings in nineteenth century were built as masks, loaded with all sorts of different symbols which no longer have the same significance and meaning as they used to. In this way, beauty becomes merely the overload of references to the antiquity, ignorant of the contemporary needs and possibilities. Nietzsche finds references to the antiquity asynchronous with the development in the other arts, especially music. At the end of this aphorism he poses the question: "If our modern music could move stones, would it set them together in the manner of the architecture of antiquity?"24 This suggests further that it has already happened, and not in the Renaissance. He was most likely thinking of Baroque architects that refrained from using the language of antiquity, but rather inventing the form that was novel and adequate to arts, technology and senses of its time.

His last critique of contemporary architectural practice has been prophetic in a sense that shortly after his death the modernist architects made parallels between automobiles and Parthenon ${ }^{25}$ and building in "primitive" forms and lines trying to resensualise architecture.

Although we can trace his growing interest for architecture through Nietzsche's opus, where he tries to position it in his mental hierarchy of arts, their origins and effects, aphorisms with architecture as keyword are scarce. This opens the way for a lot of speculation. Nevertheless, one is clear that the idea of beauty in a building could not be intentional but it "enters the system accidently." ${ }^{26}$ It is the epitaph for the eclectic architecture of nineteenth century and an omen of modernist architecture relieved of burden of significance. 


\section{2}

3

4

5

6

7
Ibid, 12.

Ibid, 13.

Ibid, 14.

Ibid, 49.

Ibid, 15.

Ibid, 16.

Ibid, 18.

Ibid, 33.

Baukunst (Germ.)

Rausch (Germ.) - translated as well as frenzy or ecstasy

Friedrich Nietzsche, The Anti-Christ, Ecce Homo, Twilight of the Idols, and Other Writings (Cambridge: University Press, 2005), 195.

Ibid, 196.

Ibid, 197.

Ibid, 197.

Michel Foucault, Power/Knowledge: Selected Interviews and Other Writings 1972-1977 (New York: Pantheon Books, 1980), 194.

Friedrich Nietzsche, Human, All too Human (Cambridge: University Press, 1996), 100.

Ibid, 100.

Ibid, 100 .

Ibid, 101.

Ibid, 101.

Ibid, 101.

Ibid, 101.

Ibid, 102.

Le Corbusier, Towards a new architecture (New York: Dover Publications Inc., 1986), 4.

Friedrich Nietzsche, Human, All too Human (Cambridge: University Press, 1996), 101. 
Nietzsche, Friedrich. Die Geburt der Tragödie in: id. Das Hauptwerk, Bd. III. München: nymphenburger, 1993.

Nietzsche, Friedrich. "Menschliches, Allzumenschliches.” In Das Hauptwerk, Bd. I. München: nymphenburger, 1993.

Nietzsche, Friedrich. “Götzen-Dämmerung.” In Das Hauptwerk, Bd. IV. München: nymphenburger, 1993.

Tarnas, Richard. The Passion of the Western Mind. Understanding the ideas that have shaped our world view. London: Pimlico, 2010.

Gleiter, Jörg H. Der philosophische Flaneur. Nietzsche und die Architektur. Würzburg: Königshausen \& Neumann, 2009

Watson, Peter. Ideas. A history from fire to Freud. London: Orion, 2005.

“Also sprach Nietzsche.” Philosophie Magazin. Special Edition 8 (June 2011). Berlin: Philomagazin Verlag GmbH. 2017

Williams, Bernard. "Nietzsche's Centaur." London Review if Books vol.3. no. 10 (June, 1981): 17. Available at: https://www.lrb.co.uk/v03/n10/bernard-williams/nietzsches-centaur. 
utkane u asocijativni, oscilirajući tok misli, često komentarušući urbanog šetača kao glumca u kapitalističkom društvu. Za razliku od toga, Niče smatra da doživljaj arhitektonskog prostora može biti sagledan kao sveobuhvatna sinteza unutrašnjeg života i spoljašnjeg iskustva, tj. preplitanje misli i pokreta, udomljujući (pomirujući) novu kreativnu dispoziciju sa stanjem svesti.

KLJUČNE REČI: FRIDRIH NIČE, VALTER BENJAMIN, FLANEUR, ATMOSFERA, URBANI PEJZAŽ, METROPOLA

\section{EPISTEMOLOŠKE IMPLIKACIJE NEUROARHITEKTURE}

\section{Hana Samaržija}

Ovaj rad će pokušati da objasni kako prostorne karakteristike izgrađenih okruženja utiču i na kognitivne procese proizvodnje znanja i epistemički kvalitet drugih logika ubeđenja. Skorije diskusije u filozofiji i društvenim naukama eksplicitno govore o promenjivoj dinamici savremenog života. Kako zamagljene granice između rada i slobodnog vremena primoravaju pojedince da utroše najveći deo svog vremena u izgrađenim okruženjima, lična iskustva prostora, objekata i enterijera postaju odlučujući faktor u samo-percepciji i spoznaji. Ove okolnosti su ohrabrile dolazak nove naučne oblasti: neuroarhitekture, ogranka funkcionalnog dizajna podržanog tehnologijom neurološkog skeniranja mozga i konceptom neuroplastičnosti, odnosno kapaciteta mozga da promeni svoju strukturu paralelno sa našim ponašanjem i okolinom. Ovaj rad nakon razmatranja ambicija neuroarhitekture da definiše najpoželjnije prostore po kriterijumu pozitivnih emocija, dobrog zdravlja, i intelektualne krepkosti, kritički će proceniti svoje epistemološke implikacije i njen potencijalno nepovoljan uticaj na arhitektonsku estetsku autonomiju. Ovaj upliv prirodnih nauka u prividno artistički domen arhitekture podseća nas na razlike između tradicionalnih analitičkih filozofija - koje su se bavile idealizovanim modelima intelektualnih i mentalnih procesa - i uvidom nauke u ljudske spoznaje, možda najbolje ilustrovana teorijom identiteta uma-mozga.

KLJUČNE REČI: NEUROARHITEKTURA, EPISTEMOLOGIJA, SPOZNAJA, UM-MOZAK IDENTITET, FILOZOFIJA UMA

\section{PREDSTAVLJANJE FRAGMENTARNOG U MODERNOJ ARHITEKTURI}

\section{Adria Daraban}

Pojam fragmentarnog u filozofskim i umetničkim diskursima obeležava početak moderne estetike i njihovo odvajanje od koncepta celine. Ovaj rad ilustruje moguća rezonantna polja oko pojma fragmentarnog u arhitekturi koji postavlja pitanja: Može li arhitektura biti oblik izražavanja savremenog stanja fragmentarnog? Da li se pojam fragmenta razvija u arhitekturi na sličan način kao i u oblastima vizuelne umetnosti, filozofije i književnosti, ili je fragment u arhitekturi sveden isključivo na oblik prezentovanja preseka? Može li se fragmentarno definisati kao pojam uslovljen vremenom i tako osloboditi od uobičajenog tumačenja pojma kao slike o isečku?

KLJUČNE REČI: FRAGMENT, HANS ŠARUN, AVANGARDNA ARHITEKTURA U NEMAČKOJ, NEMAČKI ROMANTIZAM, OGIST RODEN, FUTURIZAM

\section{KOLATERALNA LEPOTA: NICEOVA RAZMIŠLJANJA 0 ARHITEKTURI}

\section{Mirza Vranjaković}

Sa svojim tumačenjem apolonijskog i dionizijskog stanja u psihologiji, Niče (Nietzsche) je pokušavao da poveže eminentne dihotomije svoje ere - razum i instinkt, nauku i metafiziku, iskustvo i promišljanje, znanje i inspiraciju, pojavnost i celinu, red i haos. Kroz ovaj dualizam, on se kritički osvrće na celokupno nasledje zapadnjačke kulture. Predmetni rad analizira nekolicinu Ničeovih aforizama koji su direktno ili indirektno odnose na "umetnost izgradnje". Kroz aforizme, Niče je prizivao ideju nove arhitekture koja će se usprostaviti idealu zgrade devetnajstog veka: arhitektura ne idealizuje, ona nije samo pojava, već je izgrađena u duhu svog vremena, i navodi da se u nju uselimo, i na kraju, u arhitekturi lepota nije kraj već sredstvo za postizanje cilja. 